\section{THE STUDY OF A GENUS OF LAND SNAILS.1}

$\mathrm{T}^{\mathrm{H}}$ HE Rev. J. F. Gulick, in an important paper published by the Linnean Society in I873, described the distribution of the land snails belonging to the family Achatinellinæ that are found in the Hawaiian islands, and pointed out that neighbouring valleys in these islands, although presenting the same environmental conditions, are inhabited by distinct species. He regarded this as an example of a diversity of evolution under one set of external conditions which was rendered possible by isolation in the different valleys.

Darwin had stated in "The Origin of Species" that isolation is an important element in the modification of species through natural selection. But if the environmental conditions in the localities inhabited by distinct species are in all essential respects the same, natural selection takes no part in the evolution of species, and we must assume some inherent tendency to evolution, some vis a tergo which works along definite lines of divergence independently of external conditions. The question is one of very great importance, and further investigations both on the variations of the shells and on the conditions of their environment were greatly needed. In the magnificent memoir before us Prof. Crampton supplies the materials for reopening the discussion.

Partula, belonging to the family Bulimulidæ, is one of the genera of snails, confined to certain islands in the South Pacific Ocean, which show a distribution of distinct species in adjacent valleys similar to that of the Achatinellinæ in Hawaii.

The author has collected and examined an enormous number of shells, has personally studied the habits of the snails in their localities, and has put together his copious notes on the vegetation, meteorology, and topography of the islands. The present volume deals only with the species of Tahiti, but we are promised further volumes on the species of the genus from other localities.

As a detailed study of a single genus, however, this volume is the most complete of anything of the kind that has yet been attempted, and we may congratulate the author on the conclusion of this the first stage of his most laborious task.

To illustrate his study of the local conditions, we are provided with a large number of maps and sketches of a topographical model of the island, with many excellent photographs of the vegetation, and with tables of temperature and rainfall; and to illustrate the species he describes there are fifteen excellent coloured plates. For each of the species and varieties of the species in the island the author gives us the mean value of the measurements of the shells and of the apertures of the shells, together with the standard deviation, and in many cases the results are plotted out in frequency polygons.

1 "Studies on the Variation. Distribution, and Evolution of the Genus Partula." By Prof. H. E. Crampton. Pp. $342+34$ plates. (Carnegie Institution of Washington, $19+6$.$) Price 55$ dollars.

NO. 2504 , VOL. IOO]
Limitations of space do not permit further reference to the details given in this very laborious piece of work-a work which will prove essential to those who are interested in the problem of the differentiation of species.

It may be disappointing that the author does not state more decisively what his conclusions are from this elaborate study, but, although the material is already so extensive, it is perhaps wise, on his part, to delay his statement of conclusions until the series of memoirs is completed. It is clear, however, that the author is convinced that differences of environmental conditions cannot be held responsible for the differentiation of the species and varieties. In dealing with the widely spread species, Partula otaheitana, for example, he says that "the role of the environment is to set the limits to the habitable areas, or to bring about the elimination of individuals whose qualities are otherwise determined-that is, by congenital factors"; but, of course, there is no suggestion as to the cause of the change or diversity of the congenital factors.

The facts that are given in various chapters which seem to have a bearing on Mendelian inheritance are, as the author admits, not very satisfactory. Breeding experiments on an extensive scale can alone determine whether there is in Partula a Mendelian segregation similar to that described by Lang in Helix. The evidence of the occurrence of mutations, also, other than the dextral-sinistral mutation, which does not, as a rule, help to differentiate species, is not by any means conclusive.

It seems quite possible that, with the wealth of species, sub-species, and varieties which this memoir reveals and illustrates, the conclusion may be drawn that, after all, the genus Partula may afford an example of the evolution of species by the accumulation of small variations, although the cause of this accumulation still remains a mystery.

S. J. H.

\section{CONTINUATIVE EDUCATION AND ITS OBJECTS.}

A COMMITTEE of Scottish teachers, chosen A from all branches of school education, has recently issued a report entitled "Reform in Scottish Education," " which covers a wide field and embraces a large variety of topics. Many of the reforms advocated have already been set forth by others, and, in particular, by the Workers' Educational Association. In common with the latter body, the Scottish committee recommends the raising of the leaving-school age of the primary school to fifteen years; the reduction of the size of classes, so that every teacher shall have not more than forty pupils under his charge at any one time; and the establishment of day continuation schools, to which all shall be compelled to go from fifteen to eighteen, unless they are already in attendance upon a course of secondary instruction. The committee also demands the abolition of the

1 Report of the Scottish Education Re'orm Committee. (34 North Bridge. Edinburgh.) Price $1 s$. net. 